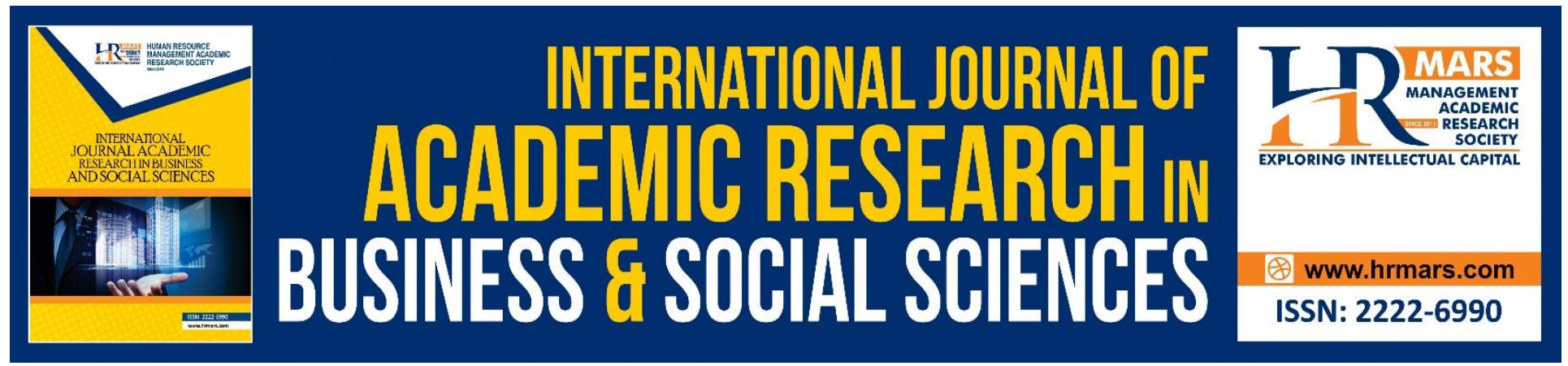

\title{
Indirect Relationship among Leadership Styles, Self-Efficacy and Academic Employees' Performance in Malaysian Online Distance Learning Higher Education Institutions
}

\section{Zahir Osman}

To Link this Article: http://dx.doi.org/10.6007/IJARBSS/v10-i8/7717

DOI:10.6007/IJARBSS/v10-i8/7717

Received: 15 May 2020, Revised: 04 June 2020, Accepted: 20 July 2020

Published Online: 16 August 2020

In-Text Citation: (Osman, 2020)

To Cite this Article: Osman, Z. (2020). Indirect Relationship among Leadership Styles, Self-Efficacy and Academic Employees' Performance in Malaysian Online Distance Learning Higher Education Institutions. International Journal of Academic Research in Business and Socail Sciences. 10(8), 1093-1104.

\section{Copyright: (C) 2020 The Author(s)}

Published by Human Resource Management Academic Research Society (www.hrmars.com)

This article is published under the Creative Commons Attribution (CC BY 4.0) license. Anyone may reproduce, distribute, translate and create derivative works of this article (for both commercial and non-commercial purposes), subject to full attribution to the original publication and authors. The full terms of this license may be seen

at: http://creativecommons.org/licences/by/4.0/legalcode

\section{Vol. 10, No. 8, 2020, Pg. 1093 - 1104}




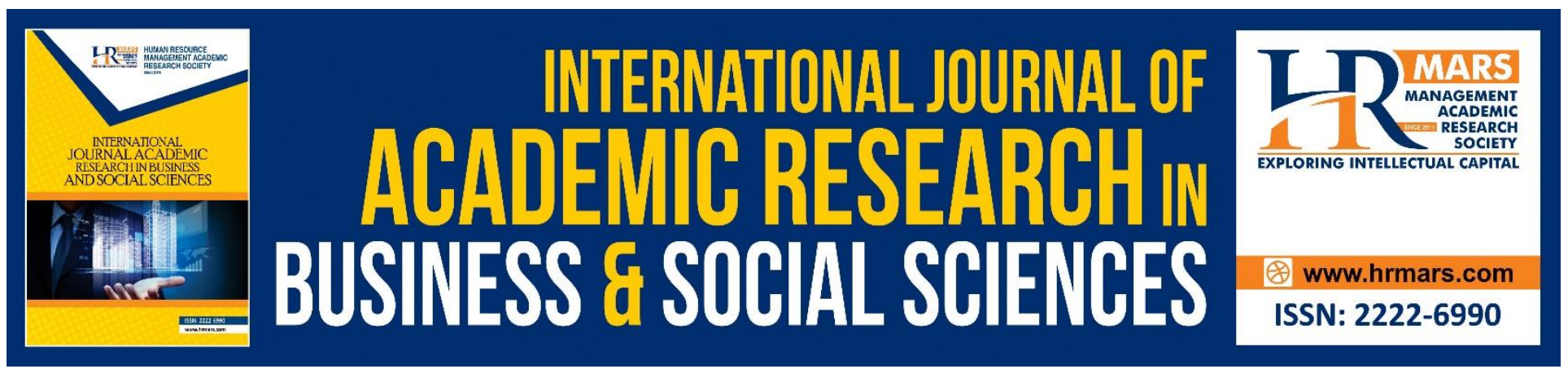

\title{
Indirect Relationship among Leadership Styles, Self- Efficacy and Academic Employees' Performance in Malaysian Online Distance Learning Higher Education Institutions.
}

\author{
Zahir Osman \\ Cluster of Business of Management, Open University Malaysia, Malaysia
}

\begin{abstract}
The purpose of this study is to evaluate the indirect relationship of self-efficacy, leadership styles and academic employees' performance in Malaysian online distance learning (ODL) higher education institutions. This study was conducted on 206 respondents of academic employees in ODL higher education institutions in Malaysia. The model was developed and later was tested and analyzed by using Partial Least Square (PLS) procedure. Findings from this study has revealed that self-efficacy has a positive and significant influence on the relationship between leadership styles and academic employees' performance in Malaysian online distance learning (ODL) higher education institutions. The findings suggested that it is very important for the leaders in ODL higher education institutions to adopt suitable leadership styles and promote self-efficacy to ensure their academic employees' performance can be elevated to greater heights to ensure the sustainability of their organizations. Smartpls 2.0 and SPSS 18.0 were employed for this study to test the hypothesis and analyze respondents' profile respectively
\end{abstract}

Keywords: Leadership Styles, Self-efficacy, Employee Performance, Online Distance Learning,

Higher Education Institutions.

\section{Introduction}

There are many challenges faced by the higher education institutions today in order to provide quality education to their students. Higher education system success depends on the hard work, effort and contribution of the academicians. Therefore, the performance of the academicians in higher education institutions becomes very important and greater emphasis must be given on this issue. Employees' performance in higher education institutions as shown in many studies were greatly affected by the leadership style of their leader (Ahmad \& Khalid, 2016). Leadership is deemed to be as one of the important elements in the organization's success where the leader can influence the behavior and actions of the employees and at the same time attaining their organizational objectives. Theoretically, teaching profession not much difference from other profession where academic 
employees usually have problems such as unhappiness where they have more tendency to be less committed and less productive and would not perform to their best (Abdullah, Ahsan \& Alam, 2009). Academicians always play an imperative role in education system in any part of the world to ensure the success of their higher education institutions and they always deemed as an important assets to their institutions. Therefore, academicians' performance will always be a top priority in all higher educational institutions (Khan et al., 2012). Higher education in Malaysia is increasing growing where higher education institution is growing exponentially. The academicians' performance during their teaching in the class will be greatly affecting the success of their institutions. Students' academic performance largely depends on the academic staff performance and other factors such as students' self-efficacy, time management and motivation (Osman et al., 2018). There is no exceptional in online distance learning environment. In order to continue the growth, it is very important for online distance learning institutions to hire competent academicians. Online distance learning, although is no longer at its infant stage and have achieved its maturity, the issue of its academics' performance is still being questioned (Allen \& Seaman, 2013). According to Noordin \& Jusoff, (2009), academicians' positive performance in their work will result better performance of the higher education institutions and eventually will make the higher education institutions more sustainable in the future. According to Howell, Brown \& Cooper (2012), organizational has influence on the employees and this can affect their work attitude, sense of obligation and responsibility on their co-worker and the organization as a whole. Therefore it is vital to focus on the main important part of organization culture on both between individuals and within a group (Grigoryan, 2015). In view of the above, the aim of this study is to evaluate whether self-efficacy mediates the relationship between leadership style and academic employees' performance on online distance learning institutions in Malaysia.

\section{Literature Review}

Social Cognitive Theory (SCT) developed by Bandura (1986) stated that self-influence mostly trigger an individual behavior. As main element of SCT, self-efficacy is an individual judgment about a person self potential to accomplish a certain task (Mitchell et al., 1994). Therefore, a person perception of efficacy foresees a person behavior and performance (Bandura, 1986). Bandura (1977) also argued that self-efficacy can influence a person activities' choice, the amount of effort used in performing task, and a person determination to deal with challenges, and eventually a person behavior and performance. Bandura (1977) proposed "a self concept reflects people's beliefs in their personal efficacy". Other study proposed self-efficacy can be related to self esteem of task based (Carson et al., 1997) and further concurred by Haycock et al., (1998) in other study. By increasing and strengthening self-esteem, employees are able to maximize their potency after gone through frustration and obtain self-confirmation (Tjosvold \& Tjosvold, 1995). In view of that, it can be looked that an individual's behavior is changed and affected by a role played by self-efficacy. Stronger selfefficacy usually will produce excellent result covering stronger job satisfaction to higher performance (Judge \& Bono, 2001). Ability to mastering the high self-efficacy component can result much better performance in assigned tasks. Lev \& Kieslowski, (2009) mentioned that self-efficacy is linked to the employee performance where they are working. Salman et al., (2016) in their study on employees of public hospital of Lahore, Pakistan have found that self-efficacy has positive and significant influence on employee performance at their work place. Carter et al., (2018) in their study on Australian financial services firms has revealed that self-efficacy has a positive and significant influence on 
INTERNATIONAL JOURNAL OF ACADEMIC RESEARCH IN BUSINESS AND SOCIAL SCIENCES Vol. 10, No. 8, 2020, E-ISSN: 2222-6990 @ 2020 HRMARS

employee performance. Study conducted by Olida, Tom \& Bilbert (2015) has found that self-efficacy played an important role and has a positive and significant influence on employee performance.

According to Tannenbaum, Weschler and Mussarik (1961), leadership can be described as interpersonal influence exercised in a situation and directed, through the communication process, toward the attainment of the specialized goal or goals". It is an instruction given to the followers to complete an intended goal (Northouse, 2004). It is a process when a person put forth a pressure purposely on the individuals in an organization via relationship, structure, and guide (Yukl, 2008). According to Sharma \& Jain (2013), leadership involves a process where individuals are persuaded by a person to get the job done and attain the objective through the instruction made. Democratic leadership, as suggested by Dahl (1989); Fishkin (1991), is where people are influenced in a constant approach via democratic values and practices which encourages inclusiveness, participation and selfdetermination. Khan et al. (2015) mentioned most autocratic leadership is where most of the power and decision making acquired by the leader. Autocratic leaders are very dominant and always the focus point in every activity that takes place and all authority come from them (Melling \& Little, 2004). Yeh \& Hong (2012) in their study on Taiwanese shoes companies' employees has found that leadership style has a strong positive and significant influence on employees' performance in their work. According to Dhaifallah (2016) in his study on female nurses in Saudi Arabia hospitals has revealed that leadership style has a positive and significant impact on the employees' performance at their work place. Study done by Ojokuku, Odetayo \& Sajuyigbe (2012) found that leaership styles has a positive and significant influence on the employee performance in banking sector in Nigeria. Findings by Ojokuku et al. (2012) were well supported by Dalluay \& Jalagat (2016) findings where in their study on small businesses in Cavite, Philippines, they found that employee performance were positively and significantly influence by leadership style. Widayanti \& Putranto (2015) when conducting their study on PT.TX Bandung employees in Indonesia has found that leadership style played an important role in determining employee performance. Their study showed there was a positive and significant relationship between leadership style and employee performance. Howell, Neufeld \& Avolio (2005), discovered that leadership style was positively related to employee performance among the managers. Dvir \& Shamir (2002) in their study suggested that employee performance was positively influenced by leadership style. Schepers \& de Ruyter (2005), in their study also revealed that employee performance and organization commitment was positively and significantly influenced by leadership styles. Many studies conducted to show the relationship of organization commitment and employee performance.

In view of the above conceptual development, the following hypotheses are proposed for this study:

$H_{1}$ : There is positive and significant relationship between leadership styles and academic employees' performance in Malaysian online distance learning institutions.

$\mathrm{H}_{2}$ : There is positive and significant relationship between leadership styles and selfefficacy in Malaysian online distance learning institutions.

$H_{3}$ : There is positive and significant relationship between self-efficacy and academic employees' performance in Malaysian online distance learning institutions. 
INTERNATIONAL JOURNAL OF ACADEMIC RESEARCH IN BUSINESS AND SOCIAL SCIENCES Vol. 10, No. 8, 2020, E-ISSN: 2222-6990 @ 2020 HRMARS

$H_{4}$ : There is a mediating effect of self efficacy on the relationship between leadership styles and academic employees' performance in Malaysian online distance learning institutions.

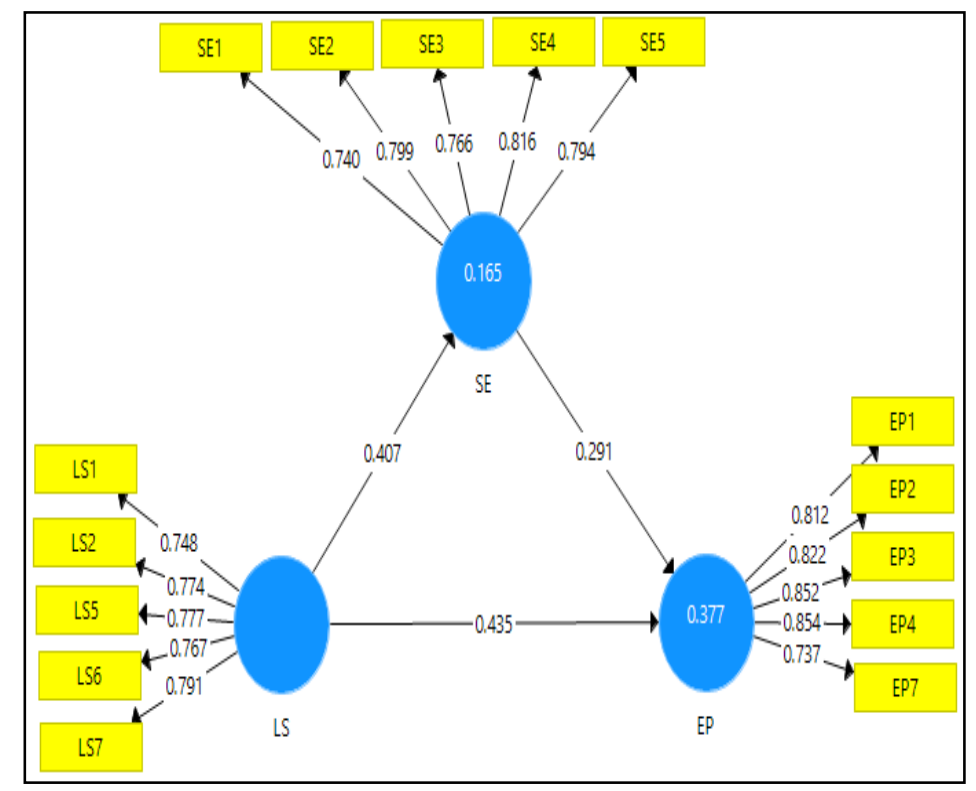

Figure 1: Research Framework

\section{Methodology}

This study adopts quantitative research approach and using primary data. Collection of primary data was done by using survey questionnaire. Extensive evaluation of literatures was done to find appropriate scales that being utilized in previous studies which were valid and reliable. There was a total of 21 observed represented the measurement of independent variable of leadership style 7 items. Mediating variable of self-efficacy has of 7 items and dependent variable of employee performance consists of 7 items. All the 21 items used Five point Likert scale from strongly disagree to strongly agree to measure. The main respondents for this study were local online distance learning institutions academic employees. From the total of 290 questionnaire distributed, 217 were returned. This made up $71 \%$ response rate and it is sufficient to conduct data analysis using structural equation modeling analysis. Total of 212 were completed from the 217 returned questionnaire, and 206 questionnaires were ready for analysis after screening and removing outliers, For multivariate data analysis, in order to evaluate the model and test the proposed hypotheses, this study utilized Smartpls3 (Ringle, Wende \& Becker, 2015). To assess the overall assessment and the relationship among the variables and their measurements, this study employed PLS-SEM technique which has the capability to do it (Hair et al., 2010). Firstly, PLS-SEM used to assess the measurement through PLSSEM algorithm. After that, the assessment of the structural model was done by running the bootstrapping procedure before reporting the results. To test the significance relationship in the model, bootstrapping technique as proposed by Preacher \& Hayes (2004) was utilized. 
INTERNATIONAL JOURNAL OF ACADEMIC RESEARCH IN BUSINESS AND SOCIAL SCIENCES Vol. 10, No. 8, 2020, E-ISSN: 2222-6990 @ 2020 HRMARS

\section{Data Analysis}

\section{Common Method Bias}

One of the main issues in conducting research in the field of management is common method bias. The issue of common method bias arises when variance suppose to represent the constructs, however represents the measurement method in the study. The utilization of Harman's single factor test is one of the methods to assess the measurement items biasness in the study. The principal factor which indicated $36.57 \%$ has assured the common method bias absence since the variance explained majority did not held by the principal factor. This is consistent with Podsakoff \& Organ, (1986) who proposed that there is no problem with common method bias if the principal component's variance explained percentage is not greater than $50 \%$.

\section{Measurement Model}

For construct validity and reliability measurement, the measurement model was used by applying PLS-SEM Algorithm (Figure 1). Hair et al., (2016) suggested that, for that reason, reliability and validity were the two crucial elements to be used in analysis of PLS-SEM to assess the goodness of outer model. Table 1 showed the figure of 0.888 to 0.909 which represents the first order constructs composite reliability, hence attain the threshold of 0.70 (Hair et al., 2014). Furthermore, the results showed that the convergent validity has met for all latent constructs with the average variance extracted (AVE) ranged from 0.595 to 0.666 which were all greater than of 0.50 (Hair, et al., 2016). Items cross loading were evaluated for further validation of the discriminant validity in this study. The result showed that all items loadings were higher than their corresponding cross loadings (Table 2). The presence of discriminant validity was further confirmed by assessing the Hetrotrait-Monotrait (HTMT) ratio of correlation developed by Henseler, Ringle \& Sarstedt (2015). The outcome of HTMT ratio analysis in Table 3 depicted that all ratios attained the HTMT criterion which was smaller than 0.85 (Kline, 2011) and as a result, showed the presence of discriminant validity. In view of that, this study proved the reliability and validity of the latent variables (Hair et al., 2014). Therefore, based on the above measurement model analysis, this study has proven the reliability and validity of the latent variables (Hair et al., 2014).

Table 1: Construct Validity \& Reliability

\begin{tabular}{ccccc}
\hline & CA & rho_A & CR & AVE \\
\hline EP & 0.874 & 0.876 & 0.909 & 0.666 \\
LS & 0.830 & 0.832 & 0.880 & 0.595 \\
SE & 0.845 & 0.863 & 0.888 & 0.614 \\
\hline
\end{tabular}


INTERNATIONAL JOURNAL OF ACADEMIC RESEARCH IN BUSINESS AND SOCIAL SCIENCES Vol. 10, No. 8, 2020, E-ISSN: 2222-6990 @ 2020 HRMARS

Table 2: Cross Loading

\begin{tabular}{llll}
\hline & EP & LS & SE \\
\hline EP1 & $\mathbf{0 . 8 1 2}$ & 0.476 & 0.357 \\
EP2 & $\mathbf{0 . 8 2 2}$ & 0.446 & 0.414 \\
EP3 & $\mathbf{0 . 8 5 2}$ & 0.414 & 0.406 \\
EP4 & $\mathbf{0 . 8 5 4}$ & 0.471 & 0.421 \\
EP7 & $\mathbf{0 . 7 3 7}$ & 0.452 & 0.305 \\
LS1 & 0.365 & $\mathbf{0 . 7 4 8}$ & 0.372 \\
LS2 & 0.377 & $\mathbf{0 . 7 7 4}$ & 0.280 \\
LS5 & 0.431 & $\mathbf{0 . 7 7 7}$ & 0.309 \\
LS6 & 0.485 & $\mathbf{0 . 7 6 7}$ & 0.304 \\
LS7 & 0.464 & $\mathbf{0 . 7 9 1}$ & 0.304 \\
SE1 & 0.268 & 0.304 & $\mathbf{0 . 7 4 0}$ \\
SE2 & 0.371 & 0.292 & $\mathbf{0 . 7 9 9}$ \\
SE3 & 0.264 & 0.252 & $\mathbf{0 . 7 6 6}$ \\
SE4 & 0.482 & 0.385 & $\mathbf{0 . 8 1 6}$ \\
SE5 & 0.382 & 0.329 & $\mathbf{0 . 7 9 4}$ \\
\hline
\end{tabular}

Table 3: Hetrotrait-Monotrait Ratio (HTMT)

\begin{tabular}{llll}
\hline & EP & LS & SE \\
\hline EP & & & \\
LS & 0.646 & & \\
SE & 0.522 & 0.475 & \\
\hline
\end{tabular}

\section{Structural Model}

For this study, path coefficient and the $\mathrm{R}^{2}$ value were used to evaluate the structural model (Hair et al., 2012), and to confirm the significance of the path coefficients, PLS bootstrapping with 500 subsamples was employed. Hypotheses test results, path coefficients and t-values are shown in Table 4 \& 5, In table $4 \& 5$, hypothesis 1 predicts a positive relationship between leadership styles and employees' performance and the result shows that there is a positive and significant influence of leadership styles on employees' performance $(B=0.435, t=6.224)$; as a result, $H 1$ is supported. The result of hypotheses 2 also revealed a significant and positive relationship between leadership styles and self-efficacy ( $B=0.407, t=6.454$ ); thus supporting $H 2$. Hypotheses 3 also showed that selfefficacy has a positive and significant influence on employees' performance $(B=0.291, t=4.234$ ), therefore, $H 3$ is supported. Hypotheses 4 result also shows that there is a positive and significant mediating effect of self-efficacy on leadership styles and employees' performance relationship (indirect effect $=0.283, t=5.670$ ); therefore $H 4$ is supported. Also, there was no zero straddle between lower level confidence of interval (LLCI) and upper level confidence of interval (ULCI) which also confirmed the significant mediating effect. 
INTERNATIONAL JOURNAL OF ACADEMIC RESEARCH IN BUSINESS AND SOCIAL SCIENCES Vol. 10, No. 8, 2020, E-ISSN: 2222-6990 @ 2020 HRMARS

Table 4: Direct Hypotheses Testing Results

\begin{tabular}{|c|c|c|c|c|}
\hline & Beta & $\begin{array}{c}\mathrm{T}- \\
\text { value }\end{array}$ & $P$ values & \\
\hline LS -> & & & & Supported \\
\hline EP & 0.435 & 6.224 & 0 & \\
\hline LS -> & & & & Supported \\
\hline SE & 0.407 & 6.454 & 0 & \\
\hline SE -> & & & & Supported \\
\hline EP & 0.291 & 4.234 & 0 & \\
\hline
\end{tabular}

Table 5: Mediating Hypotheses Results (LS -> SE -> EP)

\begin{tabular}{cccccc}
\hline & T- & P & & & \\
Beta & value & values & LLCI2.5\% & ULCI97.5\% & \\
\hline 0.118 & 3.456 & 0.001 & 0.058 & 0.184 & Supported \\
\hline
\end{tabular}

\section{Discussion}

\section{Theoretical Implications}

From the findings, it's clearly show that self-efficacy does affect the relationship between leadership styles and academic employees' performance in Malaysian online distance learning higher institutions. It is quite interesting indication from the results that many academicians in ODL higher institutions believe that leadership styles do have influence on their performance in their organizations. Therefore, it is very important for the Malaysian ODL higher education institutions to place greater emphasis on the leadership styles of their leaders. This is true because the leaders in ODL higher education institutions are the drivers of their institutions and will bring their organizations to the greater heights through the strong performance especially the academic employees. Since the results has highlighted the positive and significant role of academic employees' self-efficacy, much actions needed to be taken to boost their self-efficacy so that the impact of leadership styles will be much greater on academic employees' performance. This is very important to ensure the sustainability of the ODL higher education institutions in the future and at the same time fulfill the needs of their stakeholders especially the students.

\section{Managerial Implications}

As mentioned earlier, academic employees' performance and leadership styles in ODL higher education institutions in Malaysia is positively and significantly mediated by self-efficacy. There are many implications from this study. Firstly, it indicates that ODL higher education institutions leaders in Malaysia should strengthen their leadership styles. The right leadership styles will bring many positive things in their institutions especially with regards to their academic staff which is considered as one of the key resources in ODL higher education institutions. By strengthening leadership styles alone is not enough. Academic employees' self-efficacy must be strengthened as well. The reason is, by strengthening self-efficacy, we can see the impact of leadership styles on academic employees' performance will be more prevalent. The statistical analysis above clearly show that through direct relationship between leadership styles and academic employees' performance, there is a positive and significant relationship, but after self-efficacy was introduced as a mediator, the relationship was further strengthened. The total indirect effect leadership styles to self-efficacy and from self-efficacy 
to employee performance was $0.507^{*} 0.291=0.118$. Therefore, the leaders of ODL higher education institutions in Malaysia must ensure that through their leadership, it can bring up the performance of academic employees in their organization in delivering their duty to the students especially on academic matters which is the core business of their organizations. At the same time, leaders in ODL organizations must be able to promote and uplift the self-efficacy of their academic employees. Leaders of ODL higher education institutions in Malaysia must take steps to formulate strategies to elevate the performance of their academic employees by incorporating their leadership styles and academic employees' self-efficacy.

\section{Limitation and Future Direction}

One of the limitations in this study is the use of convenience sampling in data collection for data analysis. Even though there are some advantages by adopting convenience sampling technique, such as easy to find respondents, there are some limitations such as unable to generalize. Time is another limitation to meet paper's academic requirement. This paper was prepared in line on academic research effort which there was a time limit. Hence, there was the minimum of time on data collection to facilitate data compilation and analysis. In view of that, it is proposed that in future research, study should be done by adopting longitudinal study in order to have longer time period for collection of data. This will allow better conclusion and detailed implications can be drawn out. Wider constructs that have impact on academic employees' performance should be given consideration such as organizational commitment and organizational culture.

\section{Conclusion}

The focal point of this study is on leadership styles, self-efficacy and academic employees' performance of ODL students in online distance learning education institutions in Malaysia. The results have shown that there is indirect effect of self-efficacy on leadership styles and academic employees' performance. It was statistically found to be positive and significant. Leaders must influence the performance of their employees by encouraging the employees to work in a way that they believe best for them with proper leadership guidance from their leader. Leaders should treat their academic employees with respect and at the same time allow their academic employees to be creative and innovative in their work which eventually will bring their performance to the greater heights.

\section{References}

Abdullah, Z., Ahsan, N., \& Alam, S. S. (2009). The effect of human resource management practices on business performance among private companies in Malaysia. International Journal of Business and Management, 4(6), 65-72.

Ali, A., \& Rehman, K., (2016). The impact of leadership styles on the performance of academicians Sci. Int. (Lahore) ,28(6),153-160, ISSN 1013-5316; CODEN: SINTE 8

Allen, I. E., \& Seaman, J. (2013). Changing course: Ten years of tracking online education in the United States. Sloan Consortium. PO Box 1238, Newburyport, MA 01950.

Almutairi, D. O. (2016). The mediating effects of organizational commitment on the relationship between transformational leadership style and job performance. International Journal of Business and Management, 11(1), 231. 
INTERNATIONAL JOURNAL OF ACADEMIC RESEARCH IN BUSINESS AND SOCIAL SCIENCES Vol. 10, No. 8, 2020, E-ISSN: 2222-6990 @ 2020 HRMARS

Bandura, A. (1977). Self-efficacy: toward a unifying theory of behavioral change. Psychological review, 84(2), 191.

Bandura, A. (1986). Social foundations of thought and action. Englewood Cliffs, NJ, 1986, 23-28.

Carson, K. D., Carson, P. P., Lanford, H., \& Roe, C. W. (1997). The effects of organization-based selfesteem on workplace outcomes: An examination of emergency medical technicians. Public Personnel Management, 26(1), 139-155.

Carter, W. R., Nesbit, P. L., Badham, R. J., Parker, S. K., \& Sung, L. K. (2018). The effects of employee engagement and self-efficacy on job performance: a longitudinal field study. The international journal of human resource management, 29(17), 2483-2502.

Dahl, R. A. (1989). Democracy and its Critics. Yale University Press.

Dalluay, V. S., \& Jalagat, R. C. (2016). Impacts of Leadership Style Effectiveness of Managers and Department Heads to Employees' Job Satisfaction and Performance on Selected Small-Scale Businesses in Cavite. Philippines. International Journal of Recent Advances in Organizational Behaviour and Decision Sciences (IJRAOB), 2(2), 734-751.

Dvir, T., Eden, D., Avolio, B. J., \& Shamir, B. (2002). Impact of transformational leadership on follower development and performance: A field experiment. Academy of management journal, 45(4), 735-744.

Fishkin, J. S. (1991). Democracy and deliberation: New directions for democratic reform (Vol. 217). New Haven, CT: Yale University Press.

Grigoryan, A. E. (2015). In search of eco-friendly strategies for the development of information and communication environment. Bulletin of the Oryol State University. Series: New Humane Studies, 1(42), 297-300.

Hair, J. F., Anderson, R. E., Babin, B. J., \& Black, W. C. (2010). Multivariate data analysis: A global perspective (Vol. 7): Pearson Upper Saddle River.

Hair, J. F., Sarstedt, M., Ringle, C. M., \& Mena, J. A. (2012). An assessment of the use of partial least squares structural equation modeling in marketing research. Journal of the academy of marketing science, 40(3), 414-433.

Hair, J. J. F., Hult, G. T. M., Ringle, C., \& Sarstedt, M. (2014). A primer on partial least squares structural equation modeling (PLS-SEM). Thousand Oaks: Sage.

Hair, J. J. F., Hult, G. T. M., Ringle, C., \& Sarstedt, M. (2016). A primer on partial least squares structural equation modeling (PLS-SEM). Sage publications.

Haycock, L. A., McCarthy, P., \& Skay, C. L. (1998). Procrastination in college students: The role of selfefficacy and anxiety. Journal of counseling \& development, 76(3), 317-324.

Henseler, J., Ringle, C. M., \& Sarstedt, M. (2015). A new criterion for assessing discriminant validity in variance-based structural equation modeling. Journal of the academy of marketing science, 43(1), 115-135.

Howell, A., Kirk-Brown, A., \& Cooper, B. K. (2012). Does congruence between espoused and enacted organizational values predict affective commitment in Australian organizations?. The International Journal of Human Resource Management, 23(4), 731-747.

Howell, J. M., Neufeld, D. J., \& Avolio, B. J. (2005). Examining the relationship of leadership and physical distance with business unit performance. The Leadership Quarterly, 16(2), 273-285.

Judge, T. A., \& Bono, J. E. (2001). Relationship of core self-evaluations traits-self-esteem, generalized self-efficacy, locus of control, and emotional stability-with job satisfaction and job performance: A meta-analysis. Journal of applied Psychology, 86(1), 80. 
INTERNATIONAL JOURNAL OF ACADEMIC RESEARCH IN BUSINESS AND SOCIAL SCIENCES Vol. 10, No. 8, 2020, E-ISSN: 2222-6990 ๑ 2020 HRMARS

Khan, S., Gul, S., Shah, I. M., \& Khan, A. (2012). Teachers' stress, performance \& resources. International Review of Social Sciences and Humanities, 2(2), 10-23.

Khan, M. S., Khan, I., Qureshi, Q. A., Ismail, H. M., Rauf, H., Latif, A., \& Tahir, M. (2015). The styles of leadership: A critical review. Public Policy and Administration Research, 5(3), 87-92.

Kline, R. B. (2011). Principles and practice of structural equation modeling (Vol. 3rd). New York: Guilford publications.

Lev, S., \& Koslowsky, M. (2009). Moderating the collective and self-efficacy relationship. Journal of Educational administration.

Melling, M., \& Little, J. (Eds.). (2002). Building a successful customer-service culture: a guide for library and information managers. Facet Publishing.

Mitchell, T. R., Hopper, H., Daniels, D., George-Falvy, J., \& James, L. R. (1994). Predicting self-efficacy and performance during skill acquisition. Journal of Applied Psychology, 79(4), 506.

Noordin, F., \& Jusoff, K. (2009). Levels of job satisfaction amongst Malaysian academic staff. Asian social science, $5(5), 122-128$.

Northouse, P. G. (2004). Leadership theory and practice 3rd Ed Sage. Thousand Oaks, CA.

Ojokuku, R. M., Odetayo, T. A., \& Sajuyigbe, A. S. (2012). Impact of leadership style on organizational performance: a case study of Nigerian banks. American journal of business and management, 1(4), 202-207.

Olido, K., Tom, A., \& Bilbert, U. (2015). The Importance of Self Efficacy and Employee Competences in Employee Performance: The Case of Finca Uganda, Micro Deposit Taking Institution (MDI) In Uganda. Journal of Emerging Trends in Economics and Management Sciences (JETEMS), 9(1), 40-44.

Osman, Z., Mohamad, W., Mohamad, R. K., Mohamad, L., \& Sulaiman, T. F. T. (2018). ENHANCING STUDENTS'ACADEMIC PERFORMANCE IN MALAYSIAN ONLINE DISTANCE LEARNING INSTITUTIONS. Asia Pacific Journal of Educators and Education, 33, 19-28.

Podsakoff, P. M., \& Organ, D. W. (1986). Self-reports in organizational research: Problems and prospects. Journal of management, 12(4), 531-544.

Preacher, K. J., \& Hayes, A. F. (2004). SPSS and SAS procedures for estimating indirect effects in simple mediation models. Behavior research methods, instruments, \& computers, 36(4), 717-731.

Ringle, C. M., Wende, S., \& Becker, J. M. (2015). SmartPLS 3. SmartPLS GmbH, Boenningstedt. Journal of Service Science and Management, 10(3).

Salman, M., Khan, M. N., Draz, U., Iqbal, M. J., \& Aslam, K. (2016). Impact of self-efficacy on employee's job performance in health sector of Pakistan. American Journal of Business and Society, 1(3), 136-142.

Schepers, J., Wetzels, M., \& de Ruyter, K. (2005). Leadership styles in technology acceptance: do followers practice what leaders preach?. Managing Service Quality, 15(6), 496-508.

Sharma, M. K., \& Jain, S. (2013). Leadership management: Principles, models and theories. Global Journal of Management and Business Studies, 3(3), 309-318.

Tannenbaum, R. W., \& Mussarik, (1961), Leadership \& Organization, McGraw - Hill, USA, p. 86

Tjosvold, D., \& Tjosvold, M. M. (1995). Cooperation theory, constructive controversy, and effectiveness: Learning from crises. Team effectiveness and decision making in organizations, 79112. 
INTERNATIONAL JOURNAL OF ACADEMIC RESEARCH IN BUSINESS AND SOCIAL SCIENCES Vol. 10, No. 8, 2020, E-ISSN: 2222-6990 @ 2020 HRMARS

Widayanti, A. T., \& Putranto, N. A. R. (2015). Analyzing relationship between transformational and transactional leadership style on employee performance in PT. TX Bandung. Journal of Business and Management, 4(5), 561-568.

Yeh, H., \& Hong, D. (2012). The mediating effect of organizational commitment on leadership type and job performance. The journal of human resource and adult learning, 8(2), 50.

Yukl, G. (2008). The importance of flexible leadership. In Robert B. Kaiser (Chair), The Importance, Assessment, and Development of Flexible Leadership, practitioner forum presented at the 23rd annual conference of the Society for Industrial-Organizational Psychology, April, San Francisco, CA (pp. 2-7). 